\title{
Considering the benefits of hosting refugees: evidence of refugee camps influencing local labour market activity and economic welfare in Rwanda
}

\author{
Craig Loschmann ${ }^{1 *} \mathbb{D}$, Özge Bilgili ${ }^{2}$ and Melissa Siegel ${ }^{1}$
}

\author{
* Correspondence: c.loschmann@ \\ maastrichtuniversity.nl \\ ${ }^{1}$ Maastricht Graduate School of \\ Governance, Maastricht University | \\ UNU-MERIT, Maastricht, the \\ Netherlands \\ Full list of author information is \\ available at the end of the article
}

\begin{abstract}
This paper examines the influence of Congolese refugees on host communities in Rwanda, with a focus on labour market activity and economic welfare. The analysis takes advantage of newly collected survey data from three refugee camps and their surrounding areas to compare individuals and households within communities at various distances from, and therefore exposure to, the refugee population. We find evidence that residing close to a refugee camp makes it more likely that an individual is engaged in wage employment in comparison to farming or livestock production, representing a shift away from subsistence farming activities. In addition, there is evidence that females living nearby a camp have a higher occurrence of selfemployment in business both as a primary and secondary activity, highlighting a notable gender-specific dynamic. Likewise, living in close proximity to a camp is associated with greater household asset ownership, benefiting both male- and female-headed households similarly, whereas no relationship is found in regard to ones' subjective perception of their household's economic situation. These generally encouraging results illustrate that refugees need not be a burden to their host societies, and their presence results in direct and indirect benefits.
\end{abstract}

JEL Classification: O12, F22, R23, J24, I31, J60

Keywords: Refugees, Host communities, Labour market, Assets, Rwanda
"Since [the refugees] are our neighbours, we work hand in hand in businesses or agricultural activities to see how we can develop."

- Respondent nearby Kigeme refugee camp (2016) 
et al., 2015; IDMC, 2016; Martin, 2016). And while the so-called migration crisis in Europe has helped highlight the issue across popular media, it is important to keep in mind that the burden of displacement disproportionately falls on some of the poorest countries neighbouring those origin areas in conflict. The vast majority of refugees for example, $89 \%$, reside in other developing nations, and $34 \%$ are located in fragile states (World Bank 2016a). It is not just the immediate humanitarian concerns that need to be in focus then, but also fundamental medium- to long-term impacts of displacement that should be considered within a broader development-oriented agenda.

Despite clear relevance and greater attention given by the international community as of late, there has been relatively limited academic research on the impact of refugees on host populations, especially in low-income countries. Scholars routinely highlight how the sudden influx of refugees may bring both costs and benefits to host communities. These effects encompass economic, social and political domains and may change over time given the likelihood of refugees to experience a protracted displacement and to settle permanently in the long run. Moreover, the channels through which they influence local communities and how different subgroups are affected are still far from clear. Indeed, one of the seminal writings on the topic is that of Chambers (1986), who argues that the presence of a refugee camp can have mixed consequences for the host community depending on local conditions and differing characteristics of individuals and households.

Using this conjecture as a jumping off point, this article examines the influence of the Congolese refugee camps on host communities in Rwanda with a focus on labour market activity and economic welfare. The case in question provides a unique example as Rwanda hosts more than 80,000 refugees from the Democratic Republic of Congo (DRC), with a large share of this population in a protracted situation (UNHCR 2018). Moreover, the integrative policy approach of Rwanda that promotes economic and social interaction between the refugees and the host communities provides an interesting environment to study this topic. The analysis takes advantage of newly collected household survey data from three Congolese refugee camps and their surrounding areas. More specifically, we look at communities at various distances from the refugee populations and hence with different levels of opportunities for interaction. This underlying variation in exposure to refugees makes it possible to analyse the role refugee camps play in the economic lives of host communities.

This paper builds on and contributes to a growing literature interested in the economic impacts of forced migration. Despite advances in recent years, scholarly insight in this area is predominately of the qualitative or descriptive nature focusing on a small number of geographical areas (for example, western Tanzania). Only in the last few years have more quantitatively oriented studies begun to emerge looking at a wider variety of contexts (see Ruiz and Vargas-Silva 2013, for a detailed review). Further still, just a handful examine the impact of refugee populations restricted to a camp setting, as opposed to refugee populations integrated into society more generally (see, for example, Alix-Garcia et al. 2018). It is within this area that our study makes its main contribution. On the basis of the assumption that living at varying distances from refugee camps is associated with different levels of exposure and interaction, we provide empirical evidence on the effect of Congolese refugee camps on host communities in Rwanda. The unique research design and sampling of households within $10 \mathrm{~km}$ as well as beyond $20 \mathrm{~km}$ from three refugee camps make possible direct inference based on the 
comparison of host community households more vs. less exposed to the refugee population.

A few key conclusions can be drawn from the analysis regarding the labour market activities and economic welfare of Rwandan host communities. First, Rwandans residing closer to a refugee camp (within $10 \mathrm{~km}$ ) are significantly more likely on average to be engaged in wage employment in comparison to farming or livestock production. We interpret this as an indication of an overall adjustment taking place within the local labour market away from subsistence farming activities due to the immediate presence of the refugee population. Second, there is evidence that females living nearby a camp have a higher occurrence of self-employment in business both as a primary and secondary activity. This gender-specific result highlights how local population dynamics may in the long run influence gender roles due to the activation of women in the labour market. Third, living in close proximity to a camp is associated with greater household asset ownership on average, benefiting both male- and female-headed households similarly. Finally though, these positive estimates for Rwandans residing nearby refugee camps are not reflected in the subjective perception regarding a household's current economic situation. On the one hand, this may mean that Rwandans living close to a camp do not necessarily recognize the advantages they experience. On the other hand, this result also implies that they are not more likely to have negative perceptions of their household's economic situation compared to their peers who are less exposed to refugees. As discussed in the conclusion, these results have implications both on economic development of and social cohesion within the Rwandan society.

The rest of the article is organized as follows. In Section 2, we provide a review of the literature concerning the economic consequences of refugees for host communities in low-income country contexts. In Section 3, we highlight the Rwandan policy approach towards refugees and the relevant background information pertaining to Congolese refugees in order to anchor the analysis within the local context. In Section 4, we describe the data along with the empirical approach, before reporting the main results in Section 5. The results consist of several parts. We first study primary and secondary labour market activities before looking at asset ownership and subjective economic situation, both for the sample overall as well as based on gender. We conduct the same analysis by camp area in order to identify localized effects. In Section 6, we consider two robustness checks. First, to address potential selection we look at a subsample composed of those individuals and households who either were born in the host community or moved prior to the establishment of the nearest camp. Second, we make use of the Rwanda Population and Housing Census in 2012 to substantiate the results. We conclude in Section 7, first by briefly summarizing the main findings and then with a discussion of the broader policy implications.

\section{The economic consequences of refugees for host communities}

A review of the broader literature demonstrates how refugee populations may have a variety of economic consequences for host communities in developing country contexts. ${ }^{1}$ Chambers' (1986) oft-cited paper helps frame a more nuanced discussion regarding unequal effects of the presence of refugees and refugee programmes for surplus farmers, subsistence farmers and labourers with negligible or no land. Since then, most 
empirical work on the subject has made an attempt to extend this framework in order to dig deeper into some of the main economic outcomes of interest including local economic activity, labour market effects and general welfare. This review focuses on each of these themes separately.

In terms of local economic activity, the arrival of refugees has the potential to prompt economic expansion and innovation, breathing new life and dynamism into a regional economy (World Bank 2011). Callamard (1994), for instance, provides a descriptive account of flourishing trade and income-generating activity in Malawi based on the interaction between Mozambican refugees with the local population. Framed within the structural and political constraints of the environment, this robust economic activity is understood to have been driven by the lack of variety in the refugee food basket, the ability of refugees to 'misuse' the assistance programme (that is, access additional rations), and the local demand for items distributed to refugees that were not available in the limited local economy. Likewise, Whitaker (1999) highlights the economic opportunities for host communities in western Tanzania due to the influx of Burundian, Rwandan and Congolese refugees and associated relief resources. The author details an increase in market activity due to an upsurge in business and trade between local hosts and refugees, as well as the arrival of entrepreneurs from around the country. In particular, local farmers were seen selling and trading a wide range of products to the refugee and expatriate markets, while refugees provided hosts with food and non-food items received from relief distributions. Alternatively, Bakewell (2000), Polzer (2004) and Betts et al. (2014) concentrate on the integration of refugees in Zambia, South Africa and Uganda, respectively, and similarly report instances of increased trade between refugees and host communities. Particularly relevant for our particular case, Taylor et al. (2016) and Alloush et al. (2017) investigate some of the same Congolese refugee populations in Rwanda and describe active economic interaction between refugees and host communities. Through a simulation exercise, they find a significant income spill over effect from refugee camps to the host economies and speculate that refugees likewise fuelled trade between the local economy and the rest of the country. Finally, Alix-Garcia et al. (2018) present an innovative methodological approach that combines night-time lights data, official statistics and household survey data to show long-term increased economic activity around Kakuma refugee camp in Kenya.

When it comes to the consequences for the labour market, in the case of western Tanzania, Whitaker (1999) highlights that fact that refugees often represent a source of cheap labour for local agricultural producers, allowing for increased cultivation and production. Maystadt and Verwimp (2014) take a quantitative approach in the same setting, using a measure of refugee presence based on both proximity to and size of the refugee camp to provide a better source of local variation. They find evidence that local agricultural workers did face fiercer competition in the labour market due to refugees, while self-employed agricultural producers (that is, farmers) benefited from this supply of cheap labour. In addition, skilled workers outside of the agricultural sector were able to benefit from increased job opportunities in international organizations focused on refugee programmes, while those self-employed in business activities were worse off possibly as a result of increased competition from outside entrepreneurs. Ruiz and Vargas-Silva (2016) find complementary evidence to this effect, showing the refugee shock made it more likely that a native was engaged in within-household agriculture 
activity as opposed to working outside the household as employees, including as agricultural employees. This adjustment in labour market activity by natives in the presence of refugees similarly showed up with respect to casual labour, where competition with refugees is presumed high. Correspondingly, Tumen (2016) looks at the influx of Syrian refugees in Turkey, finding a modest decline in natives' informal employment and slight increase in natives' formal employment within the local economy, again indicating a local labour market adjustment due to the refugee population.

A number of these same studies also investigate changes to general welfare. Alix-Garcia and Saah (2009), for example, look at household assets as an indicator of wealth and find suggestive evidence of a positive wealth effect of refugee camps on nearby rural household and negative wealth effects on households in urban areas. They interpret this as evidence of a scenario where producer households benefited from higher prices in agricultural goods and then invested that money in durable goods. Likewise, Maystadt and Verwimp (2014) show that refugees on average had a positive impact on household consumption (per adult equivalent) even though this effect is highly differentiated by occupation as indicated above. Similarly, Maystadt and Duranton (2014) find that the refugee presence significantly increased real consumption, and turn their attention towards the channels of transmission of such a persistent and positive welfare effect. They find that the most important driver of this change was a sizable decrease in transport costs following increased road building, which continued to benefit the local population even after the refugees returned to their countries of origin. Additionally, Kreibaum (2015) studies the impact of Congolese refugees in Uganda and shows increased monthly consumption due to the refugee presence, although economically small. Despite this objective finding of improved wellbeing, the author also finds a contradicting subjective result in that on average locals felt they are worse off in areas with a higher level of refugees, and even more so when living close to settlements.

Overall, the evidence is mixed with regard to the economic impacts of refugees on host communities' economic situation. While the presence of a refugee population may indeed result in increased economic activity at the local level, it is also likely to result in important changes to the labour market as well as household welfare. Moreover, the magnitude and direction of these impacts seem to differ across different segments of the population and are highly sensitive to local conditions. With this in mind, we now turn to the particular case of Congolese refugees residing in Rwanda using a unique study design that allows us to analyse the economic effects of refugees in different localities and across subgroups of the host community.

\section{Rwanda's policy response to Congolese refugees' long-term presence}

Rwanda has hosted refugees from the Democratic Republic of Congo (DRC) for decades. As of 1 September 2016, UNHCR's Rwanda operation supports nearly 75,000 Congolese refugees (UNHCR, 2016). Nearly 90\% of Congolese refugees in Rwanda reside in one of five refugee camps that are spread throughout the country. Of these five camps Kiziba, Gihembe and Nyabiheke camps host 'old caseload' refugees-individuals that entered the country during the first or second Congo wars of the mid- to late-1990s. In 2012 and 2014, respectively, Kigeme and Mugombwa camps were established to accommodate an additional inflow of nearly 30,000 Congolese refugees that fled new outbreaks of violent conflict in Eastern DRC. 
In close collaboration with UNHCR and other stakeholders including local and international NGOs, the Rwandan government provides support to Congolese refugees within the five designated camps. All camps are provided with basic healthcare, water and sanitation. Moreover, refugee children either attend school in local communities or in the camps themselves. To more easily absorb the refugee children, local schools close to the camps have been provided with additional classrooms, teaching materials and uniforms (UN 2012). Officially, Rwanda does not impose restrictions to Congolese refugees on their right to work, access to education or freedom of movement. In principle, refugees hosted in Rwanda therefore have the opportunity to engage economically in their host communities and can consequently have an impact on local economies. Moreover, these rights can affect the refugees' level of integration into their host communities and may subsequently affect their choice of livelihood activities.

In practice, however, the local integration of Congolese refugees into host communities has been a persistent challenge. Rwanda is densely populated, and the overall high scarcity of agricultural land as well as employment opportunities has resulted in the inability for most refugees to lead sustainable, independent lives (Hovil 2011). Moreover, the refugee camps are crowded and suffer from lack of water and livelihood opportunities, while the rights to freedom of movement and work are complicated by formal procedures and costs (Easton-Calabria and Lindsay 2013). It is no surprise that many of the Congolese refugees residing in Rwanda are dependent on humanitarian aid for everyday survival (Hovil 2011). In sum, even though official policies endorse increased interaction between refugee and local populations, there exist competing economic, social and geographical forces that mitigate robust integration. As a result, how Congolese refugees influence local economies remains an open question.

\section{Methodology}

\subsection{Data}

To empirically assess the economic consequences of Congolese refugees for local communities, we rely on data originating from a household survey conducted in May 2016 across Rwanda. Of the five Congolese refugee camps, we chose the largest three to implement our survey in and around: Gihembe, Kigeme and Kiziba. Table 1 provides basic characteristics of each camp, illustrating that the absolute and relative sizes are considerable. For the most part, the entire population of each camp arrived at the time of establishment, and there has been only limited movement in or out of the camps since. Indeed, the vast majority of residents in Gihembe and Kiziba camps have been living

Table 1 Camp characteristics

\begin{tabular}{lccc}
\hline & Year established & Total population & Relative population (\%) \\
\hline Gihembe & 1997 & 14,205 & 9.49 \\
Kigeme & $2012^{*}$ & 18,646 & 19.38 \\
Kiziba & 1996 & 17,155 & 14.52 \\
\hline
\end{tabular}

Note: Calculations based on official figures from UNHCR and the Rwanda Population and Housing Census, 2012. Relative population is calculated using the local population in all sectors within $10 \mathrm{~km}$ of each camp. *Kigeme camp was first established in 1995 for Burundian refugees, closed in 2009 upon their return and reopened for the current Congolese refugee population in 2012 
there since the late 1990s, whereas nearly all of the current residents of Kigeme arrived in 2012 or 2013. As for differences across the camps, most notably Kiziba is by far the most geographically remote of the three as it is located at least a few hours' drive from the nearest town.

The sampling strategy of host communities surrounding these three Congolese refugee camps depended primarily on their distance from each camp. ${ }^{2}$ Figure 1 illustrates the research design with all cells located within a $10-\mathrm{km}$ radius from a camp indicated in orange, and the same absolute number of cells from $20 \mathrm{~km}$ onwards indicated in red, as potential candidates for enumeration. ${ }^{3}$ In addition, we used all registered markets throughout the country as an inclusion criterion for selection of a cell in order to proxy for possible economic interaction between refugees and locals.

With a master list of all possible cells, we randomly selected four in both the within $10 \mathrm{~km}$ and above $20 \mathrm{~km}$ areas around each camp, and chose one community in each with the largest population. ${ }^{4}$ Households were then randomly chosen for enumeration from a master list of all households located in the selected community, created in discussion with a community representative. Overall, our design results in a representative sample for the enumeration areas in question, namely within $10 \mathrm{~km}$ and above $20 \mathrm{~km}$ from Gihembe, Kigeme and Kiziba camps.

In particular cases, it is important to note that randomization veered slightly from this sampling strategy due to an added priority of re-tracking households in certain communities from an earlier conducted survey. ${ }^{5}$ In those cases, we randomly chose four cells from the sampling list of the prior survey and selected all communities in each until reaching the targeted number of households. Because the original sampling of households from that prior survey was also randomly assigned, this does not affect

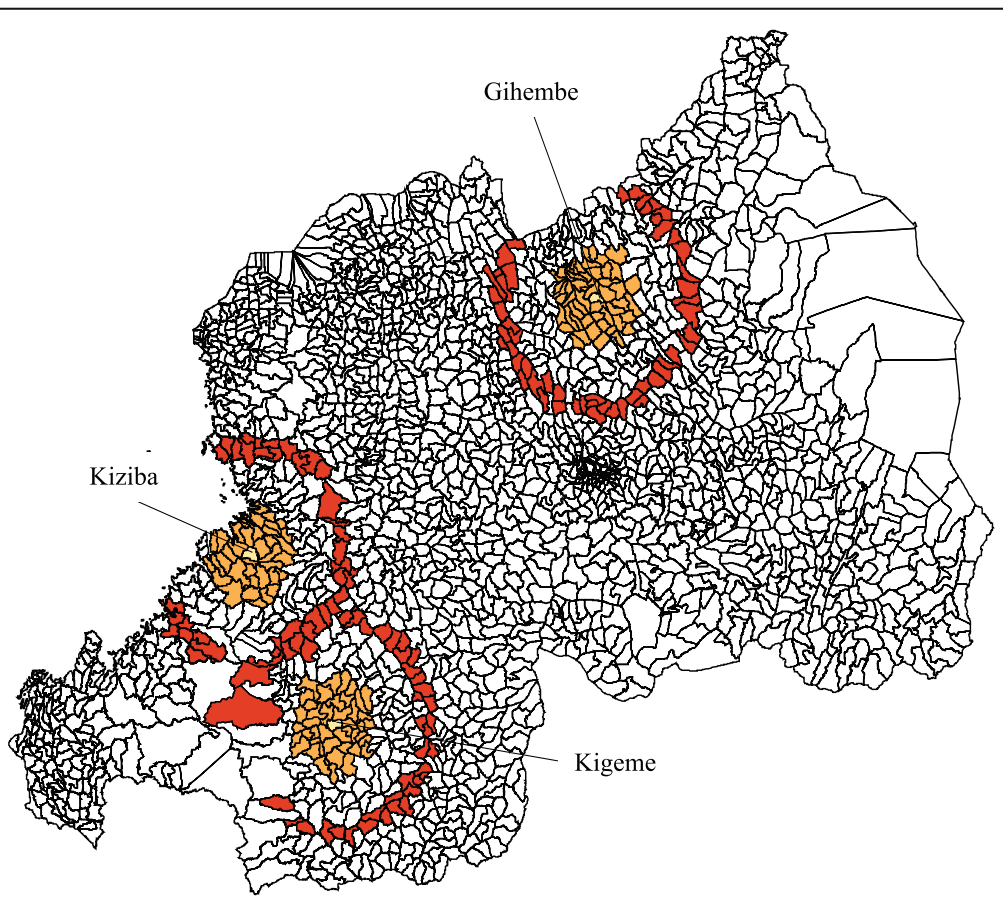

Fig. 1 Sampling strategy at the cell level. Note: Own generation based on publicly available administrative GIS data. Yellow cells indicate the location of each refugee camp. Orange cells are those within $10 \mathrm{~km}$ of each camp. Red cells are those above $20 \mathrm{~km}$ of each camp 
Table 2 Sample in host communities, by distance to the nearest camp

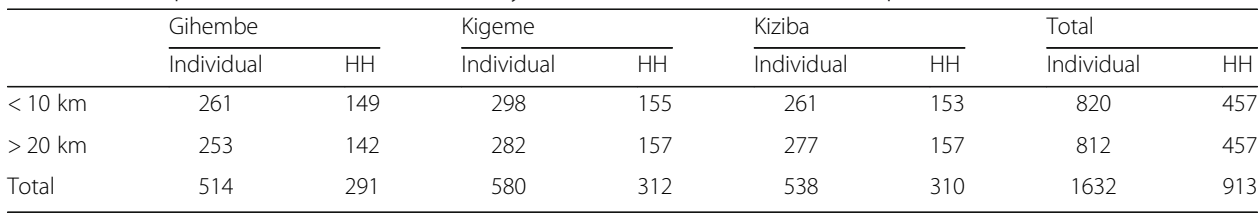

the representativeness of our own sample. Table 2 shows that the final dataset is comprised of 1632 working age individuals (aged 16 to 65) active and employed in the labour market, within 913 households. By design, the share of individuals and households in host communities outside each of the three camps is comparable.

\subsection{Empirical approach}

Considering our objective to provide evidence for the influence of refugees on host communities, our empirical approach hinges on the comparison between households that are more vs. less exposed to the refugee population. The sample was designed in such a way as to provide a counterfactual scenario with exposure based on the distance from each camp, and more precisely whether the household is located in a community within $10 \mathrm{~km}$ of a refugee camp compared to beyond $20 \mathrm{~km}$. This $10 \mathrm{~km}$ vs. $20 \mathrm{~km}$ setup was decided following pre-survey site visits and extensive discussions with stakeholders on the ground in order to gauge a high vs. low potential for interaction between refugees and host communities, and therefore a localized effect. As Alloush et al. (2017: 334) explain in their own study focusing exclusively on the $10 \mathrm{~km}$ area, "A 10-kilometer radius captures the main markets in which refugees transact. Given poor transportation infrastructure, refugees rarely engage directly with markets outside this radius."

The basic regression equation estimated can be expressed as:

$$
Y_{i}=\beta_{0}+\beta_{1} X_{i}+\beta_{2} Z_{i}+\beta_{3} D_{10 \mathrm{~km}}+u_{i}
$$

where $Y_{i}$ represents one of the four outcomes of interest for individual or household $i$ depending on the outcome in question; $X_{i}$ is the vector of individual and household control variables including gender, age, marital status, household head, education at lower secondary level, size of household and share of children (per adult); $Z_{i}$ is a vector of community controls including market distance, city distance, community population and nearest refugee camp which the community surrounds; $D_{10 \mathrm{~km}}$ is a dummy indicating whether the individual or household resides within $10 \mathrm{~km}$ of a refugee camp compared to further than $20 \mathrm{~km}$ from a camp; and $u_{i}$ is the error term. In addition, we are interested in gender- and camp-specific heterogeneous effects across the camp proximity variable and introduce subsample specifications along the lines of:

$$
\begin{aligned}
Y_{i}= & \beta_{0}+\beta_{1} X_{i}+\beta_{2} Z_{i}+\beta_{3}\left(D_{10 \mathrm{~km}} \times G_{\text {female }}\right)+\beta_{4}\left(D_{10 \mathrm{~km}} \times G_{\text {male }}\right)+u_{i} \\
& \begin{aligned}
Y_{i}= & \beta_{0}+\beta_{1} X_{i}+\beta_{2} Z_{i}+\beta_{3}\left(D_{10 \mathrm{~km}} \times C_{\text {Gihembe }}\right)+\beta_{4}\left(D_{10 \mathrm{~km}} \times C_{\text {Kigeme }}\right) \\
& +\beta_{5}\left(D_{10 \mathrm{~km}} \times C_{\text {Kiziba }}\right)+u_{i}
\end{aligned}
\end{aligned}
$$


where $G_{\text {female }}$ and $G_{\text {male }}$ are dummies indicating the gender of the individual or household head again depending on the level of the outcome in question; and $C_{\text {Gihembe }}, C_{\mathrm{Ki}-}$ geme and $C_{\text {Kiziba }}$ represent being a host community member outside one of the three Congolese refugee camps. Keep in mind, when looking at gender-specific heterogenous effects in Eq. (2), our interest is not to make a comparison between females and males, but rather between females at varying distances to the camp (i.e. females $<10 \mathrm{~km}$ vs. females $>20 \mathrm{~km}$ ), and likewise for males separately. As such, we omit the main effect for distance to the camp (i.e. $D_{10 \mathrm{~km}}$ ) in the model specification which is simply a reparameterization of the full model that includes all main effects-meaning it is qualitatively the same-in order to derive the estimate of the comparison we are interested in. The same logic applies for the camp-specific model specification in Eq. (3). In all models, we cluster standard errors within the 46 separate communities.

To assess the economic consequences, our analysis uses measures of labour market activity and economic welfare illustrated in Table 3. Concerning primary daily activity in the 12 months prior to enumeration, we see the importance of the agricultural sector as most respondents, $74 \%$ overall, are engaged in subsistence farming or livestock production which corresponds to the official 70\% estimated in 2011 (World Bank 2016b). Looking across communities based on distance to the nearest refugee camp, we find that a working age individual located within $10 \mathrm{~km}$ of a camp is nearly twice as likely to be in wage employment in comparison to someone located beyond $20 \mathrm{~km}$. A similar trend is found for self-employment in business, albeit at a lower scale, while those persons outside the $20 \mathrm{~km}$ radius are 12 percentage points more likely to be involved in farming or livestock production.

Beyond primary daily activity, respondents also indicated whether they were engaged in multiple occupations allowing us to investigate secondary activities as well. Of those individuals involved in farming or livestock production as a primary activity, around $40 \%$ said they were also involved in wage employment and $11 \%$ in self-employment. Across locations, there is no statistically significant mean difference in terms of wage employment whereas this figure is around five percentage points higher for self-employment in business within $10 \mathrm{~km}$.

With respect to economic welfare, we rely on an objective and subjective measure at the household level to indicate general wellbeing. For the former, we create an asset

Table 3 Descriptive statistics of outcomes

\begin{tabular}{|c|c|c|c|c|c|}
\hline & \multicolumn{2}{|c|}{$<10 \mathrm{~km}$} & \multicolumn{2}{|c|}{$>20 \mathrm{~km}$} & \multirow[t]{2}{*}{ Total } \\
\hline & Mean & SD & Mean & SD & \\
\hline \multicolumn{6}{|l|}{ Primary daily activity } \\
\hline Wage employment*** & 0.20 & 0.40 & 0.12 & 0.33 & 1632 \\
\hline Self-employment (business)* & 0.11 & 0.32 & 0.08 & 0.27 & 1632 \\
\hline Farming/livestock ${ }^{* * *}$ & 0.68 & 0.47 & 0.80 & 0.40 & 1632 \\
\hline \multicolumn{6}{|l|}{ Secondary activity of farming/livestock } \\
\hline Wage employment & 0.41 & 0.49 & 0.40 & 0.49 & 1205 \\
\hline Self-employment** & 0.13 & 0.34 & 0.08 & 0.28 & 1205 \\
\hline Asset ownership index (leisure items)*** & 0.03 & 0.98 & -0.31 & 0.78 & 913 \\
\hline Subjective economic situation $(1-5)^{* *}$ & 2.19 & 0.99 & 2.02 & 0.88 & 913 \\
\hline
\end{tabular}

Note: ${ }^{* *}$ indicates statistically significant mean difference across groups at the $1 \%$ level; ${ }^{* *}$ at the $5 \%$ level. The five-point Likert scale for subjective economic situation ranges from 1 (very difficult) to 5 (very comfortable) 
ownership index using multiple correspondence analysis to provide a single measure of ownership across a wide range of leisure items (see Table 16 in the Appendix). Using the first two dimensions, this index captures more than $80 \%$ of the overall variation explained in the binary data of asset ownership across all items. For the latter, we look at a categorical subjective measure of the household's economic situation based on an ordered list of five responses: very difficult (1), difficult (2), coping (3), comfortable (4) and very comfortable (5). Table 3 shows the mean differences along these outcomes across communities based on proximity to the nearest refugee camp. Households nearby a refugee camp have a statistically significant higher asset ownership score based on our index and perceive their economic situation more positively based on our 5-point Likert scale despite the average being difficult for both groups.

Moving beyond descriptive differences based on our $10 \mathrm{~km}$ vs. $20 \mathrm{~km}$ setup, in the next section, we present the empirical results controlling for a range of individual-, household- and community-level covariates shown in Table 4. To account for differences in local economic conditions, we control for travel time to the nearest market as well as distance to the nearest city (i.e. Kigali and officially categorized secondary cities). Where our unit of observation is at the household level, namely for those outcomes related to economic welfare, we collapse individual-level covariates to the level of the household head. And although we find a statistically significant mean difference based on distance to the nearest camp for a few of covariates, for example having at least lower secondary education, Table 5 shows that many of these same covariates are either not statistically significant or reversed when using data from the Rwanda Population and Housing Census in $1991 .^{6}$ Given the census data was collected prior to the establishment of the camps, this helps indicate that any difference found are not systematic and may be due to the presence of the camp itself.

Recognizing the potential for positive selection bias in our estimates, we also report the results using a limited sample as a robustness check. More specifically, it is possible that individuals voluntarily moved into the areas around refugee camps after being established in expectation of economic opportunities. To account for this potential positive selection, we restrict our sample to only those individuals who either were born in the community or moved there prior to the nearest camp's year of establishment. While it is possible that an individual was not born in the community but still

Table 4 Descriptive statistics of covariates (for working age individuals)

\begin{tabular}{lcccccc}
\hline & \multicolumn{1}{c}{$<10 \mathrm{~km}$} & & & $>20 \mathrm{~km}$ & Total \\
\cline { 2 - 3 } & Mean & SD & & Mean & SD & \\
\hline Female & 0.56 & 0.50 & & 0.56 & 0.50 & 1632 \\
Age & 37.27 & 12.53 & & 37.58 & 13.13 & 1632 \\
Married** & 0.70 & 0.46 & & 0.66 & 0.48 & 1632 \\
HH head & 0.44 & 0.50 & & 0.45 & 0.50 & 1632 \\
Lower secondary education*** & 0.18 & 0.38 & & 0.12 & 0.32 & 1632 \\
Household size*** & 5.54 & 2.08 & & 5.15 & 2.26 & 1632 \\
Share of children (per adult) & 0.97 & 0.76 & & 1.00 & 0.78 & 1632 \\
Market distance (in minutes)*** & 65.39 & 40.53 & & 77.36 & 60.70 & 1632 \\
City distance (in km)*** & 30.07 & 7.72 & & 21.83 & 7.65 & 1632 \\
\hline
\end{tabular}

Note: ${ }^{* *}$ indicates statistically significant mean difference across groups at the $1 \%$ level; ${ }^{* *}$ at the $5 \%$ level. City distance indicates the distance to nearest urban area including the capital, Kigali, as well as all secondary cities 
Table 5 Descriptive statistics of covariates (for working age individuals) using '91 census

\begin{tabular}{|c|c|c|c|c|c|}
\hline & \multicolumn{2}{|c|}{$<10 \mathrm{~km}$} & \multicolumn{2}{|c|}{$>20 \mathrm{~km}$} & \multirow[t]{2}{*}{ Total } \\
\hline & $\overline{M e a n}$ & SD & $\overline{\text { Mean }}$ & SD & \\
\hline Female & 0.52 & 0.50 & 0.53 & 0.50 & 67,952 \\
\hline Age & 32.65 & 13.14 & 32.82 & 13.13 & 67,952 \\
\hline Married ${ }^{* * *}$ & 0.61 & 0.49 & 0.58 & 0.49 & 64,930 \\
\hline $\mathrm{HH}$ head & 0.38 & 0.49 & 0.37 & 0.48 & 67,820 \\
\hline Lower secondary education & 0.04 & 0.19 & 0.04 & 0.20 & 62,824 \\
\hline Household size ${ }^{* * *}$ & 5.70 & 2.66 & 5.83 & 2.63 & 67,952 \\
\hline Share of children (per adult) & 0.96 & 1.16 & 0.98 & 1.19 & 67,952 \\
\hline
\end{tabular}

Note: ${ }^{* *}$ indicates statistically significant mean difference across groups at the $1 \%$ level

within the $10 \mathrm{~km}$ area, meaning they were not selected into the area, we unfortunately do not have such detailed information and are forced to make an overly cautious adjustment by censoring everyone born outside of the community. This results in censoring the sample by around 300 individuals and 200 households, depending on the unit of analysis. Alternatively, selective outmigration from the $10 \mathrm{~km}$ area due to the establishment of the camp may also introduce bias into our estimates if those individuals who left are systematically different from those who stayed behind. While we are unable to account for this possible source of bias given the lack of information on outmigrants, we believe that the risk is small taking into consideration the relatively low internal mobility within Rwanda (World Bank 2017).

As another robustness check, we also make use of the publicly available Rwanda Population and Housing Census in 2012 to substantiate the survey results where possible. In particular, the most recent census includes information on employment status as well as the type of work based on ISCO-8 categorization. This allows for a comparable analysis looking at wage and self-employment against subsistence agricultural activities. Due to the year of the census, however, we only take into consideration those areas around Gihembe and Kiziba camps, as Kigeme only became established for its current population in 2012. Moreover, in order to conduct a parallel analysis using census data as similar as possible to our original analysis using survey data, we replicate the within $10 \mathrm{~km}$ vs. beyond $20 \mathrm{~km}$ design providing us with the localized average effect around Gihembe or Kiziba. ${ }^{7}$

Lastly, it is important to mention that the location of the camps is not random considering it was a government decision at the time of establishment, which may relate to the outcomes in question. While we are unable to account for this potential source of endogeneity, the predominant explanation from in-depth stakeholder interviews was that camps were placed where they are today simply due to land availability at that time, and therefore without consideration for local economic factors. Indeed, Kiziba camp is located on top of a mountain with relatively little access to local markets. And while land availability may indicate low quality of land, site visits confirm the prevalence of small-scale farming around each camp area. As such, we believe any inherent bias in our estimates due to this potential source of endogeneity is likely minimal.

\section{Empirical results}

In what follows, we primarily focus on the average estimates of camp proximity. Besides these average estimates, however, we also identify heterogeneous effects based on 
gender and a specific camp area. As a matter of parsimony, we do not report the range of individual, household and community-level controls specified earlier. ${ }^{8}$

Beginning first with the influence of the refugee population on the primary daily activity of host communities, Table 6 presents the results of being engaged in wage employment or self-employment in business relative to farming or livestock production. With respect to our main variable of interest, camp proximity, we find that living within $10 \mathrm{~km}$ of any refugee camp increases the likelihood of being both wage and self-employed in business in comparison to engaged in subsistence farming or livestock production, by 14 and $7 \%$ respectively when including full controls. With respect to wage employment, even though many of these individuals indicate that they still work in the agricultural sector, more than half of the sample, importantly it is distinguished from subsistence farming or own production given they are paid employees. Other common wage employment activities around the camps include construction, education and administrative services, whereas most self-employment activities are related to small-scale trading and selling. Using an interaction term to look across camp proximity and gender, we see this association for wage employment is positive and significant for both females and males within $10 \mathrm{~km}$ of a camp relative to their same gender counterparts further away, whereas for self-employment the result holds only for females.

Restricting ourselves to only those individuals who are engaged in subsistence farming or livestock production as a primary daily activity, Table 7 provides evidence that a shift in secondary activity is also occurring nearby the refugee camps and this result is driven primarily by women. Specifically, once including full controls, we see that native women are $9 \%$ more likely to be involved in self-employment activities on the side of their primary agricultural activity, with most of this being categorized as trading and selling. Again, this corresponds to the anecdotal small-scale activities taking place in and around the camps by individuals who otherwise might be involved in subsistence agricultural activity.

While enhanced local economic activity and labour market opportunities may be one of the main channels through which refugee populations influence host communities,

Table 6 Primary daily activity

\begin{tabular}{|c|c|c|c|c|c|c|}
\hline \multirow[t]{2}{*}{ Base: farming/livestock } & \multicolumn{3}{|c|}{ Wage employment } & \multicolumn{3}{|c|}{ Self-employment } \\
\hline & $(1)$ & $(2)$ & (3) & (4) & (5) & (6) \\
\hline \multirow[t]{2}{*}{ Camp proximity $(<10 \mathrm{~km})$} & $0.10^{* * *}$ & $0.14^{* * *}$ & & $0.05^{*}$ & $0.07^{* *}$ & \\
\hline & $(0.04)$ & $(0.03)$ & & $(0.03)$ & $(0.03)$ & \\
\hline \multirow[t]{2}{*}{ x Female } & & & $0.12^{* * *}$ & & & $0.08^{* *}$ \\
\hline & & & $(0.04)$ & & & $(0.03)$ \\
\hline \multirow[t]{2}{*}{ x Male } & & & $0.17^{* * *}$ & & & 0.05 \\
\hline & & & $(0.04)$ & & & $(0.03)$ \\
\hline Controls & No & Yes & Yes & No & Yes & Yes \\
\hline$R^{2}$ & 0.02 & 0.20 & 0.20 & 0.01 & 0.10 & 0.10 \\
\hline Observations & 1474 & 1474 & 1474 & 1363 & 1363 & 1363 \\
\hline
\end{tabular}

Note: ${ }^{* *} p<0.01,{ }^{* *} p<.05,{ }^{*} p<0.10$. Estimates are based on a linear probability model, but robust to maximum likelihood estimation. Standard errors in parentheses are robust and clustered at the community level (46). The omission of the main effect 'Camp proximity $(<10 \mathrm{~km})$ ' in models (3) and (6) represent a reparameterization of a full model, in order to provide the estimates for the comparisons of interest (e.g. females $<10 \mathrm{~km}$ vs. females $>20 \mathrm{~km}$ ). See Fig. 2 in the Appendix for full heterogeneous effects across gender. Other covariates controlled for include female, age, married, household head, education at lower secondary level, size of household, share of children (per adult), market distance, city distance, community population and nearest refugee camp 
Table 7 Secondary activity of those engaged in farming/livestock production

\begin{tabular}{|c|c|c|c|c|c|c|}
\hline & \multicolumn{3}{|c|}{ Wage employment } & \multicolumn{3}{|c|}{ Self-employment } \\
\hline & $(1)$ & $(2)$ & (3) & $(4)$ & $(5)$ & (6) \\
\hline \multirow[t]{2}{*}{ Camp proximity $(<10 \mathrm{~km})$} & 0.01 & -0.01 & & $0.05^{* *}$ & $0.07^{* * *}$ & \\
\hline & $(0.06)$ & $(0.06)$ & & $(0.02)$ & $(0.02)$ & \\
\hline \multirow[t]{2}{*}{ x Female } & & & -0.03 & & & $0.09^{* * *}$ \\
\hline & & & $(0.07)$ & & & $(0.03)$ \\
\hline \multirow[t]{2}{*}{ x Male } & & & 0.03 & & & 0.03 \\
\hline & & & $(0.07)$ & & & $(0.04)$ \\
\hline Controls & No & Yes & Yes & No & Yes & Yes \\
\hline$R^{2}$ & 0.00 & 0.08 & 0.08 & 0.01 & 0.02 & 0.02 \\
\hline Observations & 1205 & 1205 & 1205 & 1205 & 1205 & 1205 \\
\hline
\end{tabular}

Note: ${ }^{* *} p<0.01,{ }^{* *} p<.05,{ }^{*} p<0.10$. Estimates are based on a linear probability model, but robust to maximum likelihood estimation. Standard errors in parentheses are robust and clustered at the community level (46). The omission of the main effect 'Camp proximity $(<10 \mathrm{~km})$ ' in models (3) and (6) represent a reparameterization of a full model, in order to provide the estimates for the comparisons of interest (e.g. females $<10 \mathrm{~km}$ vs. females $>20 \mathrm{~km}$ ). See Fig. 2 in the Appendix for full heterogeneous effects across gender. Other covariates controlled for include female, age, married, household head, education at lower secondary level, size of household, share of children (per adult), market distance, city distance, community population and nearest refugee camp

one might expect this to lead to indirect welfare benefits as well. Indeed, the results presented in Table 8 illustrate how living within $10 \mathrm{~km}$ of a refugee camp is also positively associated with a household's asset ownership based on our generated index. And looking within categories, we find that both female- and male-headed households benefit similarly relative to their same gendered counterparts residing further away. On the other hand, no statistically significant estimate is found with respect to the subjective perception of the household's economic situation.

Tables 9, 10, and 11 present the results separately for each camp area in order to highlight camp-specific dynamics. Looking first at primary daily activity by camp location, Table 9 illustrates that wage employment is more likely within $10 \mathrm{~km}$ from each of the camps when including full controls, even though only those estimates in the case of Gihembe camp are statistically significant across model specifications making them

Table 8 Economic welfare

\begin{tabular}{|c|c|c|c|c|c|c|}
\hline & \multicolumn{3}{|c|}{ Asset ownership index } & \multicolumn{3}{|c|}{ Subjective economic situation } \\
\hline & (1) & (2) & (3) & (4) & (5) & (6) \\
\hline \multirow[t]{2}{*}{ Camp proximity $(<10 \mathrm{~km})$} & $0.34^{* * *}$ & $0.36^{* * *}$ & & $0.18^{*}$ & 0.13 & \\
\hline & $(0.12)$ & $(0.11)$ & & $(0.10)$ & $(0.12)$ & \\
\hline \multirow[t]{2}{*}{ x Female-headed } & & & $0.27^{* *}$ & & & -0.03 \\
\hline & & & $(0.11)$ & & & $(0.14)$ \\
\hline \multirow[t]{2}{*}{ x Male-headed } & & & $0.39^{* * *}$ & & & 0.19 \\
\hline & & & $(0.12)$ & & & (0.13) \\
\hline Controls & No & Yes & Yes & No & Yes & Yes \\
\hline$R^{2}$ & 0.04 & 0.28 & 0.28 & 0.01 & 0.10 & 0.10 \\
\hline Observations & 913 & 913 & 913 & 913 & 913 & 913 \\
\hline
\end{tabular}

Note: ${ }^{* *} p<0.01,{ }^{* *} p<.05,{ }^{*} p<0.10$. Estimates are based on a linear probability model, but robust to maximum likelihood estimation. Standard errors in parentheses are robust and clustered at the community level (46). The omission of the main effect 'Camp proximity $(<10 \mathrm{~km})^{\prime}$ in models (3) and (6) represent a reparameterization of a full model, in order to provide the estimates for the comparisons of interest (e.g. female-headed $<10 \mathrm{~km}$ vs. female-headed $>20 \mathrm{~km}$ ). See Fig. 2 in the Appendix for full heterogeneous effects across gender. Other covariates controlled for include female head, age head, married head, education head at lower secondary level, size of household, share of children (per adult), market distance, city distance, community population and nearest refugee camp 
Table 9 Primary daily activity, by camp area

\begin{tabular}{|c|c|c|c|c|c|c|}
\hline & \multicolumn{3}{|c|}{ Wage employment } & \multicolumn{3}{|c|}{ Self-employment } \\
\hline & $(1)$ & $(2)$ & (3) & $(4)$ & (5) & (6) \\
\hline \multirow[t]{2}{*}{ Gihembe $x<10 \mathrm{~km}$} & $0.24^{* * *}$ & $0.19^{* * *}$ & & $0.12^{* *}$ & $0.12^{* *}$ & \\
\hline & $(0.06)$ & $(0.06)$ & & $(0.05)$ & $(0.06)$ & \\
\hline \multirow[t]{2}{*}{ x Female } & & & $0.15^{* *}$ & & & 0.10 \\
\hline & & & $(0.06)$ & & & $(0.06)$ \\
\hline \multirow[t]{2}{*}{ x Male } & & & $0.25^{* * *}$ & & & $0.17^{* * *}$ \\
\hline & & & $(0.08)$ & & & $(0.06)$ \\
\hline \multirow[t]{2}{*}{ Kigeme $x<10 \mathrm{~km}$} & 0.03 & $0.09^{* *}$ & & 0.04 & 0.05 & \\
\hline & $(0.04)$ & $(0.03)$ & & $(0.04)$ & $(0.04)$ & \\
\hline \multirow[t]{2}{*}{ x Female } & & & 0.06 & & & $0.08^{* *}$ \\
\hline & & & $(0.04)$ & & & $(0.04)$ \\
\hline \multirow[t]{2}{*}{ x Male } & & & $0.13^{* *}$ & & & -0.00 \\
\hline & & & $(0.05)$ & & & $(0.05)$ \\
\hline \multirow[t]{2}{*}{ Kiziba $x<10 \mathrm{~km}$} & 0.03 & $0.16^{* * *}$ & & 0.01 & 0.02 & \\
\hline & $(0.04)$ & $(0.04)$ & & $(0.04)$ & $(0.04)$ & \\
\hline \multirow[t]{2}{*}{ x Female } & & & $0.16^{* * *}$ & & & 0.04 \\
\hline & & & $(0.05)$ & & & $(0.04)$ \\
\hline \multirow[t]{2}{*}{ x Male } & & & $0.16^{* * *}$ & & & 0.01 \\
\hline & & & $(0.05)$ & & & $(0.04)$ \\
\hline Controls & No & Yes & Yes & No & Yes & Yes \\
\hline$R^{2}$ & 0.05 & 0.20 & 0.20 & 0.02 & 0.10 & 0.11 \\
\hline Observations & 1474 & 1474 & 1474 & 1363 & 1363 & 1363 \\
\hline
\end{tabular}

Note: ${ }^{* *} p<0.01,{ }^{* *} p<.05,{ }^{*} p<0.10$. Estimates are based on a linear probability model, but robust to maximum likelihood estimation. Standard errors in parentheses are robust and clustered at the community level (46). The omission of the main effect 'Camp proximity $(<10 \mathrm{~km})^{\prime}$ in models (3) and (6) represent a reparameterization of a full model, in order to provide the estimates for the comparisons of interest (e.g. females $<10 \mathrm{~km}$ vs. females $>20 \mathrm{~km}$ ). See Fig. 3 in the Appendix for full heterogeneous effects across camp areas. Other covariates controlled for include female, age, married, household head, education at lower secondary level, size of household, share of children (per adult), market distance, city distance, community population and nearest refugee camp

more reliable. In addition, wage employment is greatest outside Gihembe likely indicating the geographic proximity and economic linkages to the nearby town of Byumba. Likewise, it is only those residents nearby Gihembe camp that are more likely to be self-employed in business on average, by $12 \%$.

Differentiating the camp-specific findings across gender, we find that the estimates for wage employment hold for both men and women in the cases of Gihembe and Kiziba camps, whereas only men are more likely to be wage employed in the case of Kigeme. On the other hand, higher self-employment in business is indicated for men in the case of Gihembe, while it is females nearby Kigeme camp that are particularly engaged in self-employment activities like small-scale trading and selling in that case.

Table 10 shows the camp-specific results for secondary activities of those individuals engaged in farming or livestock production as a primary daily activity. Similar to the camp-specific findings just discussed, the estimates indicate that women within $10 \mathrm{~km}$ of Kigeme camp are driving the overall results, as they are $18 \%$ more likely to be self-employed in a non-farm business as a secondary activity. The prevalence of self-employment activities for women outside Kigeme camp both as a primary and 
Table 10 Secondary activity of those in subsistence farming/livestock, by camp area

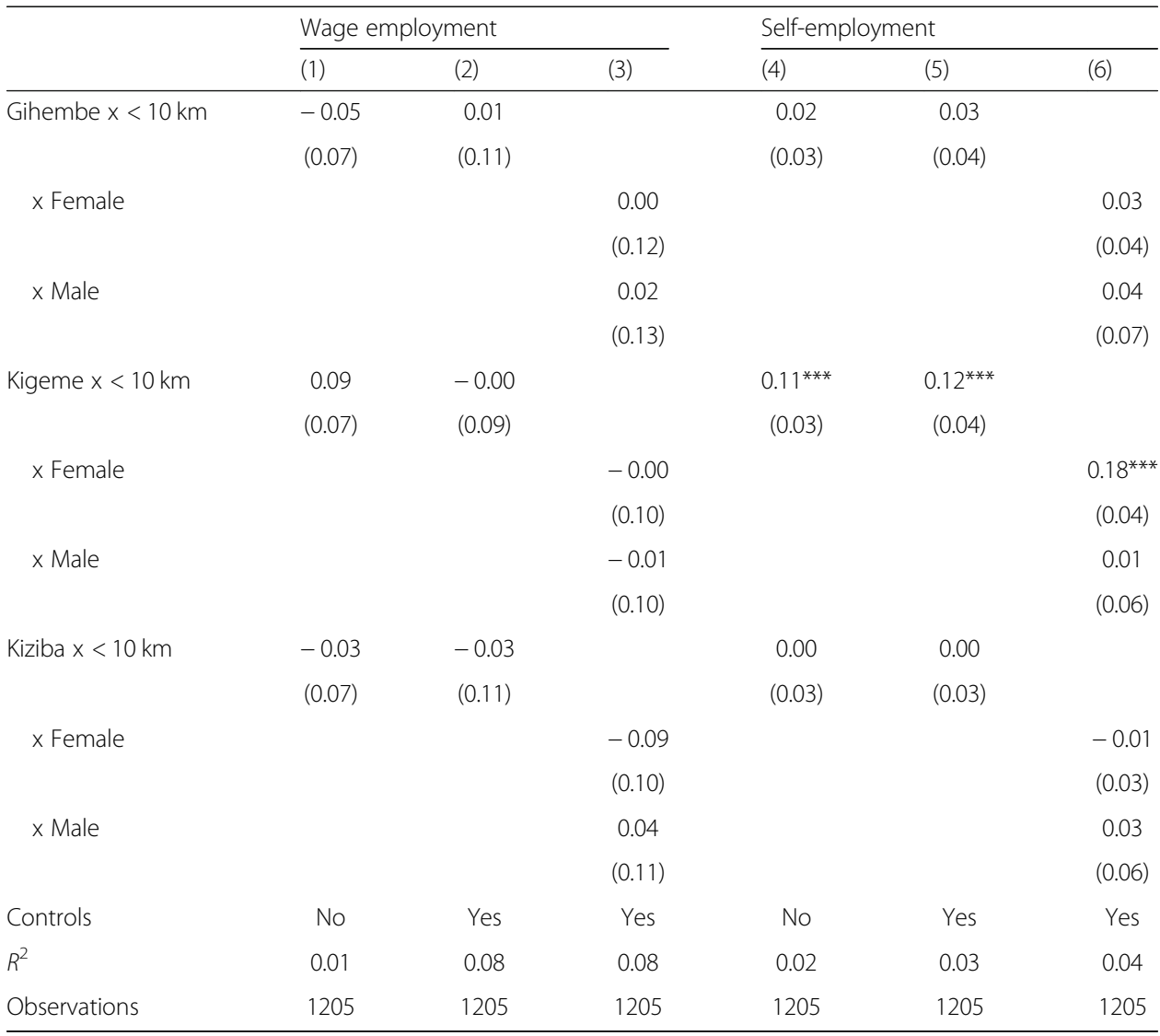

Note: ${ }^{* *} p<0.01,{ }^{* *} p<.05,{ }^{*} p<0.10$. Estimates are based on a linear probability model, but robust to maximum likelihood estimation. Standard errors in parentheses are robust and clustered at the community level (46). See Fig. 3 in the Appendix for full heterogeneous effects across all relevant subgroups. Other covariates controlled for include female, age, married, household head, education at lower secondary level, size of household, share of children (per adult), market distance, city distance, community population and nearest refugee camp

secondary activity illustrates how they are well placed to be taking advantage of small-scale market opportunities due to the refugee camp.

Lastly, when looking at the camp-specific results for economic welfare in Table 11, we find a positive estimate when including full controls for asset ownership within each of the three camp areas, even though it is only marginally statistically significant at the $10 \%$ level in the case of those households nearby Gihembe. Breaking these results down by gender, male-headed households around Kigeme are particularly better off with respect to asset ownership whereas both female- and male-headed households benefit in the case of Kiziba and Gihembe. Furthermore, we see that households nearby Kigeme perceive their economic situation more positively than those located further away, and corresponding to those estimates for assets, this result is driven my male-headed households.

\section{Robustness checks}

We here present the results of two robustness checks. First, taking into account the possibility for residents within $10 \mathrm{~km}$ of a refugee camp to have positively selected into their community since a camp was established, Tables 12, 13 and 14 report the same models as prior on a limited sample. As discussed, this limited sample is restricted to 
Table 11 Economic welfare, by camp area

\begin{tabular}{|c|c|c|c|c|c|c|}
\hline & \multicolumn{3}{|c|}{ Asset ownership index } & \multicolumn{3}{|c|}{ Subjective economic situation } \\
\hline & $(1)$ & $(2)$ & (3) & $(4)$ & (5) & (6) \\
\hline \multirow[t]{2}{*}{ Gihembe $x<10 \mathrm{~km}$} & $0.64^{* * *}$ & $0.39^{*}$ & & 0.16 & -0.24 & \\
\hline & $(0.21)$ & $(0.21)$ & & $(0.14)$ & $(0.15)$ & \\
\hline \multirow[t]{2}{*}{ x Female-headed } & & & $0.32^{*}$ & & & -0.19 \\
\hline & & & $(0.18)$ & & & $(0.16)$ \\
\hline \multirow[t]{2}{*}{ x Male-headed } & & & $0.44^{*}$ & & & -0.26 \\
\hline & & & $(0.25)$ & & & $(0.18)$ \\
\hline \multirow[t]{2}{*}{ Kigeme $x<10 \mathrm{~km}$} & $0.26^{*}$ & $0.36^{* * *}$ & & $0.36^{* * *}$ & $0.45^{* * *}$ & \\
\hline & $(0.13)$ & $(0.10)$ & & $(0.12)$ & $(0.12)$ & \\
\hline \multirow[t]{2}{*}{ x Female-headed } & & & 0.17 & & & 0.14 \\
\hline & & & $(0.13)$ & & & $(0.20)$ \\
\hline \multirow[t]{2}{*}{ x Male-headed } & & & $0.41^{* * *}$ & & & $0.54^{* * *}$ \\
\hline & & & $(0.12)$ & & & $(0.14)$ \\
\hline \multirow[t]{2}{*}{ Kiziba $x<10 \mathrm{~km}$} & 0.13 & $0.29^{* *}$ & & 0.00 & 0.19 & \\
\hline & $(0.15)$ & $(0.13)$ & & $(0.11)$ & $(0.11)$ & \\
\hline \multirow[t]{2}{*}{ x Female-headed } & & & $0.28^{* *}$ & & & 0.14 \\
\hline & & & $(0.11)$ & & & $(0.12)$ \\
\hline \multirow[t]{2}{*}{ x Male-headed } & & & $0.29^{* *}$ & & & 0.20 \\
\hline & & & $(0.14)$ & & & $(0.13)$ \\
\hline Controls & No & Yes & Yes & No & Yes & Yes \\
\hline$R^{2}$ & 0.06 & 0.28 & 0.29 & 0.02 & 0.12 & 0.13 \\
\hline Observations & 913 & 913 & 913 & 913 & 913 & 913 \\
\hline
\end{tabular}

Note: ${ }^{* *} p<0.01,{ }^{* *} p<.05,{ }^{*} p<0.10$. Estimates are based on a linear probability model, but robust to maximum likelihood estimation. Standard errors in parentheses are robust and clustered at the community level (46). See Fig. 3 in the Appendix for full heterogeneous effects across all relevant subgroups. Other covariates controlled for include female head, age head, married head, education head at lower secondary level, size of household, share of children (per adult), market distance, city distance, community population and nearest refugee camp

those individuals and households who either were born in the community or moved prior to the nearest camp opening and is an overly cautious restriction given the fact that observations are censored even if they may have been born within the $10 \mathrm{~km}$ area but not in the same community.

In comparison to the original baseline findings, using the restricted sample leads to slight changes to our estimates. Table 12 shows that living within $10 \mathrm{~km}$ of a refugee camp still results in a $14 \%$ higher likelihood of being wage employed both for men and women relative to their same gender counterparts residing beyond $20 \mathrm{~km}$ from a camp. Alternatively, those results for self-employment lose statistical significance. Similarly, Table 13 illustrates that our original results with respect to self-employment as a secondary activity do not hold in this limited sample. This change in the estimates on self-employment using the limited sample may be simply due to the lower number of observations given the sign and effect size that are comparable in both cases. However, we also cannot rule out the possibility of positive self-selection with respect to self-employment. For example, some newer arrivals may be more entrepreneurial and therefore have greater capacity to take advantage of the market opportunities a refugee camp offers with a small-scale business. Finally, Table 14 confirms that asset ownership 
Table 12 Limited sample, primary daily activity

\begin{tabular}{|c|c|c|c|c|c|c|}
\hline \multirow[t]{2}{*}{ Base: farming/livestock } & \multicolumn{3}{|c|}{ Wage employment } & \multicolumn{3}{|c|}{ Self-employment } \\
\hline & $(1)$ & $(2)$ & (3) & (4) & (5) & (6) \\
\hline \multirow[t]{2}{*}{ Camp proximity $(<10 \mathrm{~km})$} & $0.08^{* *}$ & $0.14^{* * *}$ & & 0.02 & 0.04 & \\
\hline & $(0.03)$ & $(0.03)$ & & $(0.03)$ & $(0.03)$ & \\
\hline \multirow[t]{2}{*}{ x Female } & & & $0.14^{* * *}$ & & & $0.06^{*}$ \\
\hline & & & $(0.04)$ & & & $(0.03)$ \\
\hline \multirow[t]{2}{*}{ x Male } & & & $0.15^{* * *}$ & & & 0.01 \\
\hline & & & $(0.04)$ & & & $(0.03)$ \\
\hline Controls & No & Yes & Yes & No & Yes & Yes \\
\hline$R^{2}$ & 0.01 & 0.18 & 0.18 & 0.00 & 0.08 & 0.08 \\
\hline Observations & 1132 & 1132 & 1132 & 1040 & 1040 & 1040 \\
\hline
\end{tabular}

Note: ${ }^{* *} p<0.01,{ }^{* *} p<.05,{ }^{*} p<0.10$. Estimates are based on a linear probability model, but robust to maximum likelihood estimation. Standard errors in parentheses are robust and clustered at the community level (46). The omission of the main effect 'Camp proximity $(<10 \mathrm{~km})^{\prime}$ in models (3) and (6) represent a reparameterization of a full model, in order to provide the estimates for the comparisons of interest (e.g. females $<10 \mathrm{~km}$ vs. females $>20 \mathrm{~km}$ ). Other covariates controlled for include female, age, married, household head, education at lower secondary level, size of household, share of children (per adult), market distance, city distance, community population and nearest refugee camp

is higher for those households residing nearby a camp, again both for male- and female-headed households.

Second, Table 15 presents estimates from a parallel analysis using data from the Rwanda Population and Housing Census from 2012. Taking only the working age population around each of the three camp areas, we again find evidence that living within $10 \mathrm{~km}$ of a refugee camp, in this case only Gihembe and Kiziba camps due to the year of data collection, results in a higher likelihood of being both wage and self-employed relative to being engaged in subsistence agricultural activities. Moreover, the interaction terms for men and women are likewise positive and statistically significant for both activities, supporting the earlier baseline estimates.

Table 13 Limited sample, secondary activity of those in subsistence farming/livestock

\begin{tabular}{|c|c|c|c|c|c|c|}
\hline & \multicolumn{3}{|c|}{ Wage employment } & \multicolumn{3}{|c|}{ Self-employment } \\
\hline & $(1)$ & (2) & (3) & (4) & (5) & (6) \\
\hline \multirow[t]{2}{*}{ Camp proximity $(<10 \mathrm{~km})$} & 0.03 & 0.01 & & 0.03 & 0.04 & \\
\hline & $(0.06)$ & $(0.06)$ & & $(0.03)$ & $(0.03)$ & \\
\hline \multirow[t]{2}{*}{ x Female } & & & -0.01 & & & $0.06^{*}$ \\
\hline & & & $(0.06)$ & & & $(0.03)$ \\
\hline \multirow[t]{2}{*}{ x Male } & & & 0.03 & & & 0.02 \\
\hline & & & $(0.07)$ & & & $(0.04)$ \\
\hline Controls & No & Yes & Yes & No & Yes & Yes \\
\hline$R^{2}$ & 0.00 & 0.07 & 0.07 & 0.00 & 0.02 & 0.02 \\
\hline Observations & 920 & 920 & 920 & 920 & 920 & 920 \\
\hline
\end{tabular}

Note: ${ }^{* *} p<0.01,{ }^{* *} p<.05,{ }^{*} p<0.10$. Estimates are based on a linear probability model, but robust to maximum likelihood estimation. Standard errors in parentheses are robust and clustered at the community level (46). The omission of the main effect 'Camp proximity $(<10 \mathrm{~km})$ ' in models (3) and (6) represent a reparameterization of a full model, in order to provide the estimates for the comparisons of interest (e.g. females $<10 \mathrm{~km}$ vs. females $>20 \mathrm{~km}$ ). Other covariates controlled for include female, age, married, household head, education at lower secondary level, size of household, share of children (per adult), market distance, city distance, community population and nearest refugee camp 
Table 14 Limited sample, economic welfare

\begin{tabular}{|c|c|c|c|c|c|c|}
\hline & \multicolumn{3}{|c|}{ Asset ownership index } & \multicolumn{3}{|c|}{ Subjective economic situation } \\
\hline & $\overline{(1)}$ & (2) & (3) & (4) & (5) & (6) \\
\hline \multirow[t]{2}{*}{ Camp proximity $(<10 \mathrm{~km})$} & $0.22^{* *}$ & $0.29^{* * *}$ & & 0.03 & 0.04 & \\
\hline & $(0.10)$ & $(0.10)$ & & $(0.11)$ & $(0.13)$ & \\
\hline \multirow[t]{2}{*}{ x Female-headed } & & & $0.26^{* * *}$ & & & -0.07 \\
\hline & & & $(0.10)$ & & & $(0.15)$ \\
\hline \multirow[t]{2}{*}{ x Male-headed } & & & $0.31^{* *}$ & & & 0.09 \\
\hline & & & $(0.12)$ & & & $(0.14)$ \\
\hline Controls & No & Yes & Yes & No & Yes & Yes \\
\hline$R^{2}$ & 0.02 & 0.22 & 0.22 & 0.00 & 0.07 & 0.07 \\
\hline Observations & 704 & 704 & 704 & 704 & 704 & 704 \\
\hline
\end{tabular}

Note: ${ }^{* *} p<0.01,{ }^{* *} p<.05,{ }^{*} p<0.10$. Estimates are based on a linear probability model, but robust to maximum likelihood estimation. Standard errors in parentheses are robust and clustered at the community level (46). The omission of the main effect 'Camp proximity $(<10 \mathrm{~km})^{\prime}$ in models (3) and (6) represent a reparameterization of a full model, in order to provide the estimates for the comparisons of interest (e.g. female-headed $<10 \mathrm{~km}$ vs. female-headed $>20 \mathrm{~km}$ ). Other covariates controlled for include female head, age of head, married head, education head at lower secondary level, size of household, share of children (per adult), market distance, city distance, community population and nearest refugee camp

\section{Conclusion}

This study has investigated the economic influence of the Congolese refugee population on host communities in Rwanda. The research design and empirical approach has allowed us to compare individuals and households residing within $10 \mathrm{~km}$ of one of three refugee camps to those living beyond $20 \mathrm{~km}$ from the same camps. Given the focus on local economic consequences, our analysis has concentrated on outcomes related to labour market activity and economic welfare. Namely, we have focused on primary and secondary labour activities, asset ownership and subjective assessment of economic wellbeing. Aside from average overall effects, the analysis provides the impacts of refugees in different localities and across subgroups of the host community.

Table 15 Employment activity, using 2012 census data

\begin{tabular}{|c|c|c|c|c|c|c|}
\hline \multirow{2}{*}{$\begin{array}{l}\text { Dependent variable } \\
\text { Base: agriculture }\end{array}$} & \multicolumn{3}{|c|}{ Wage employment } & \multicolumn{3}{|c|}{ Self-employment } \\
\hline & (1) & $(2)$ & (3) & $(4)$ & $(5)$ & $(6)$ \\
\hline \multirow[t]{2}{*}{ Camp proximity $(<10 \mathrm{~km})$} & $0.01^{* *}$ & $0.06^{* * *}$ & & $0.01^{* * *}$ & $0.04^{* * *}$ & \\
\hline & $(0.00)$ & $(0.01)$ & & $(0.00)$ & $(0.00)$ & \\
\hline \multirow[t]{2}{*}{ x Female } & & & $0.06^{* * *}$ & & & $0.04^{* * *}$ \\
\hline & & & $(0.01)$ & & & $(0.01)$ \\
\hline \multirow[t]{2}{*}{ x Male } & & & $0.07^{* * *}$ & & & $0.04^{* * *}$ \\
\hline & & & $(0.01)$ & & & $(0.01)$ \\
\hline Controls & No & Yes & Yes & No & Yes & Yes \\
\hline$R^{2}$ & 0.03 & 0.21 & 0.21 & 0.01 & 0.06 & 0.06 \\
\hline Observations & 61276 & 44565 & 44565 & 55119 & 39542 & 39542 \\
\hline
\end{tabular}

Note: ${ }^{* *} p<0.01,{ }^{* *} p<.05,{ }^{*} p<0.10$. Estimates are based on a linear probability model, but robust to maximum likelihood estimation. Standard errors in parentheses are robust. The omission of the main effect 'Camp proximity $(<10$ $\mathrm{km})^{\prime}$ in models (3) and (6) represent a reparameterization of a full model, in order to provide the estimates for the comparisons of interest (e.g. females $<10 \mathrm{~km}$ vs. females $>20 \mathrm{~km}$ ). Other covariates controlled for include female, age, married, household head, education at lower secondary level, size of household, share of children (per adult), city distance and the administrative sector 
Considering the results from both the baseline analysis and robustness checks, a few key findings stand out. First, residing within $10 \mathrm{~km}$ of a refugee camp makes it more likely on average that an individual is engaged in wage employment in comparison to subsistence farming or livestock production. We interpret this as indication of an overall adjustment taking place within the local labour market, with natives shifting away from subsistence agricultural activities in the presence of the refugee population potentially due to greater non-farm business opportunities and/or the ability to hire low-skilled labour to perform subsistence agricultural work. These results are in line with previous research that highlights the benefits of refugee influxes in a way to expand and bring dynamism to a local economy.

In addition to previous research that has looked at the varying effects of refugees for different segments of the local labour market based on sector, in our study, we highlight more of a gender-specific dynamic. That is, there is evidence that females living nearby a camp have a higher occurrence of self-employment in business both as primary and secondary activities compared to females in communities further away. This result is also supported by anecdotal evidence of women engaging in small-scale trading and selling in and around camps. Accordingly, we argue that besides leading to diversification of labour activities, living nearby a refugee camp may promote the inclusion of women in the local labour market and therefore impact gender roles in the long run.

In terms of economic welfare, living within $10 \mathrm{~km}$ of a refugee camp is found to also result in a household having greater asset ownership in comparison to those living beyond $20 \mathrm{~km}$. This finding holds for both female- and male-headed households, comparing to their corresponding counterparts residing further away from a camp. Alternatively, we find no indication that proximity to a camp influences subjective perceptions of the household's economic situation. Although this may mean Rwandans living close to a refugee camp do not recognize the economic advantages they experience due to the refugee population, neither do they believe themselves worse off because of the camps. These results have important implications concerning public opinion and perceptions of host communities and require further investigation.

With respect to camp-specific findings, our results vary. Wage employment within range of each camp is positive across all locations; however, the estimates are greatest for Gihembe indicating a more dynamic local economy. On the other hand, self-employment in business as a secondary activity is seen in the case of women around Kigeme, reflecting a market opportunity for small-scale selling and trading in this particular environment. While one reason for this may be due to the arrival of the refugee population only a few years prior, in 2012, it may also reflect potentially limited wage employment opportunities available around the camp. Additionally, a more positive opinion of one's economic situation is seen in the area nearby Kigeme which could be due to more direct interaction with refugees in this case. This result further confirms that it is difficult to generalize the impact of refugees in different localities as shown in previous research. Specific characteristics of each area of investigation may affect both the direction and the strength of the economic effects of refugee camps on local communities.

Taking a step back from the nuances of our findings, on the whole, it appears that the presence of the refugee population has benefited host communities in Rwanda. Just 
as important though, even in cases where we do not see a clear positive influence of living nearby a refugee camp, nor do we find any clear negative consequence. It is likely that the integrative approach of the Rwandan government with regard to refugee settlement and the absence of forced boundaries between refugees and the local community have led to a more unified labour market. While there is surely room to improve the integration of refugees in local communities in Rwanda, other countries in similar circumstances can readily look upon it as a generally successful example of how refugees need not be a burden and contribute to their host societies.

In conclusion, given the current levels of displacement around the world and the way this topic is often portrayed in popular media, the findings of this study help paint an encouraging picture. Supported by a national policy that puts emphasis on integration, refugees and local communities live together in a manner that is for the most part beneficial to both, indicating what is possible when refugees are not only welcomed by their hosts but provided the fundamental right to work. To complement this line of analysis, future research should look into other issues where refugee presence can affect the host communities. In particular, studying further social cohesion between refugees and locals, as well as the ways in which access to social services such as education and health are affected by refugee camps would be a significant step towards a better understanding of the costs and benefits of hosting refugees.

\section{Endnotes}

${ }^{1}$ While there is an interesting ongoing debate on the economic impacts of refugees in industrialized nations (see Clemens, 2017), we focus our attention here on those works that look at the impact in low-income country contexts.

${ }^{2}$ For our purposes, we define a community as the lowest administrative unit in Rwanda, otherwise known as a village.

${ }^{3} \mathrm{~A}$ cell is the second lowest official administrative unit, above the village. Country-wide data at the village level was not readily available; therefore, randomization took place at the cell level.

${ }^{4}$ Population data at the village level for those selected cells was generously made available by the National Institute of Statistics Rwanda.

${ }^{5} \mathrm{We}$ became aware of a similar research project by a team of researchers from the University of California at Davis (UC-Davis) following an initial site visit. Given the similarities between sampling designs, and the potential value added of re-surveying some of their original households, we decided to adjust course slightly from our original plan. For more information on the UC-Davis project, see Taylor et al. (2016).

${ }^{6} \mathrm{Keep}$ in mind, Rwanda experienced an infamously violent period of conflict between the 1991 census and when the first camp was opened in the 1996, upending society and causing radical change including displacement. Still, the 1991 census is the most recent pre-camp data available prior to that conflict which allows for broad temporal comparison.

${ }^{7}$ The sample using the census data is restricted to only those households $0-10$ and 20-30 km from both camps.

${ }^{8}$ The results of full models are available upon request. 


\section{Appendix}

Table 16 List of leisure items included in asset ownership index
- Large pieces of furniture
- Refrigerator
- Kitchen appliances
- Radio
- Television
- Telephone/mobile phone
- Iron
- Fans
- Stove
- Blankets
- Generator/motorized pump
- Bicycle
- Motorbike
- Car/van/truck/pick-up

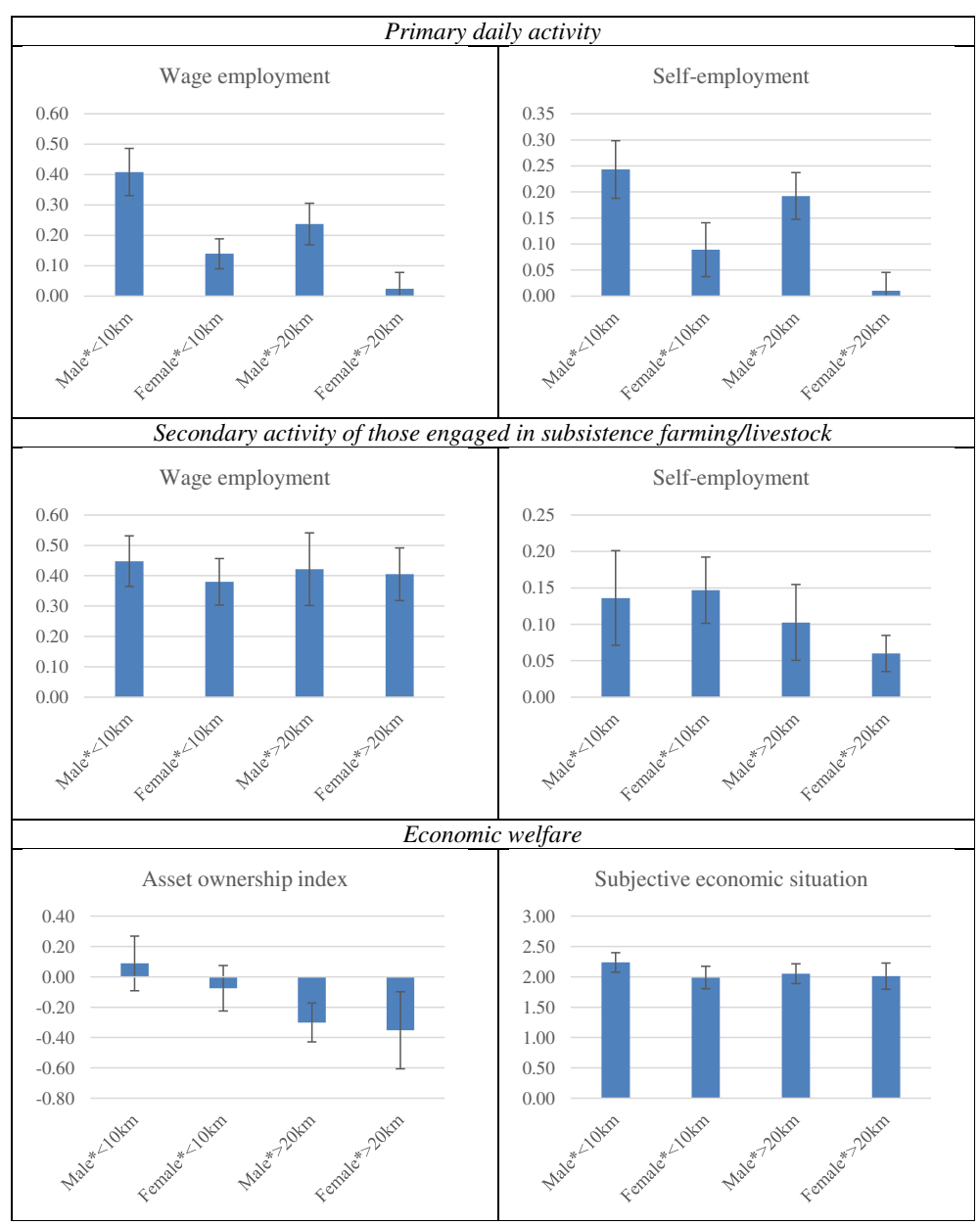

Fig. 2 Heterogeneous effects, based on gender 


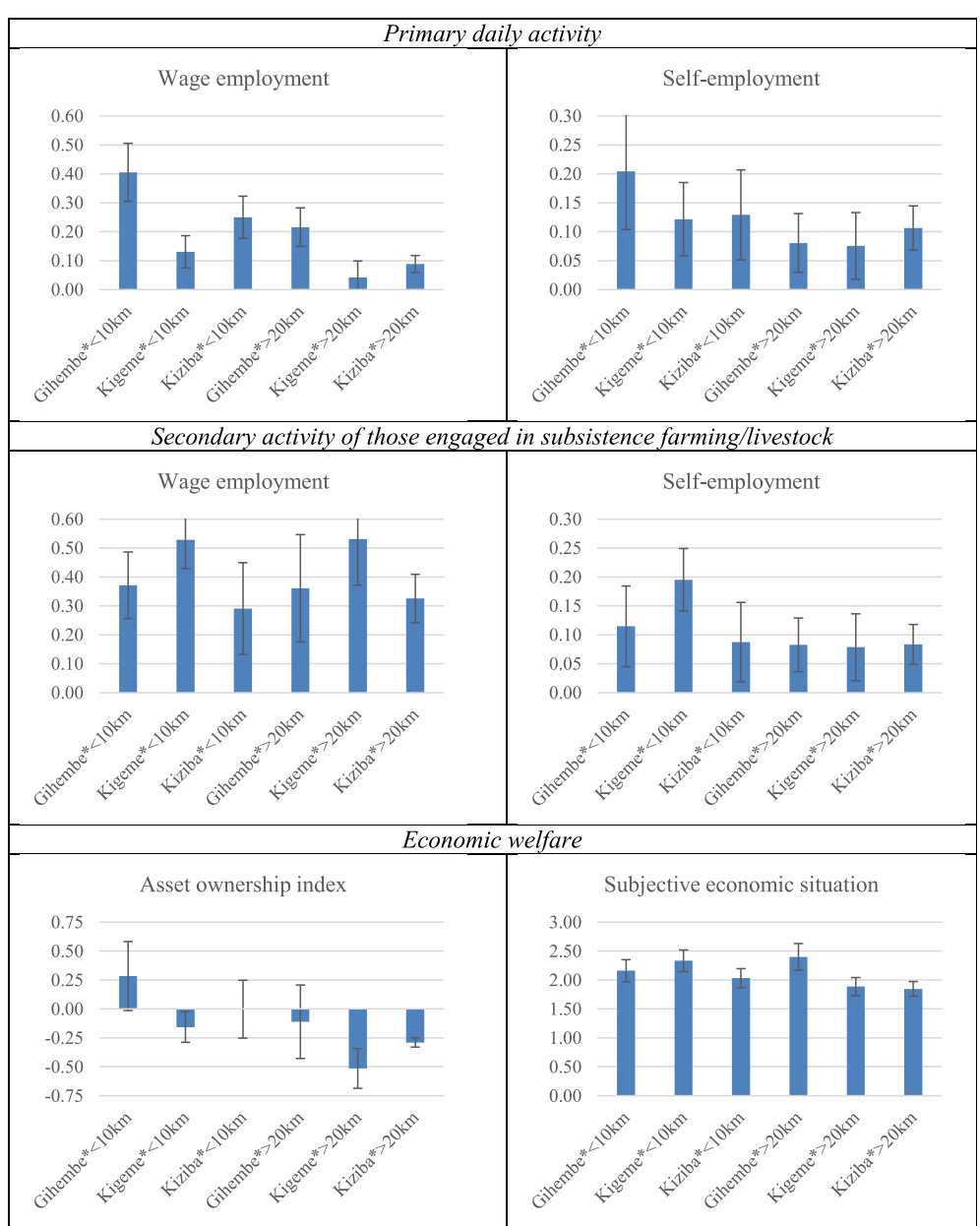

Fig. 3 Heterogeneous effects, based on camp area

\section{Acknowledgements}

We thank Sonja Fransen, Carlos Vargas-Silva and Eleonora Nillesen for invaluable feedback on earlier versions. Likewise, we received helpful feedback from participants of the "Beyond Crisis: Rethinking Refugee Studies" conference at the University of Oxford, the "Transnational Migration, Citizenship and the Circulation of Rights and Responsibilities" workshop at the European University Institute, the workshop on "Migration and Conflict" at Université Catholique de Louvain, and the $10^{\text {th }}$ AFD-World Bank Conference on Migration and Development. This paper is a result of a project funded by the United Nations High Commissioner for Refugees (UNHCR), but which was independently carried out by researchers from the Maastricht Graduate School of Governance | UNU-MERIT. We are thankful of the UNHCR's sub-country office in Kigali, as well as the National Institute of Statistics Rwanda (NISR) for their support during fieldwork. We would also like to thank the anonymous referee and the editor for the useful remarks.

Responsible editor: Jackline Wahba

\section{Funding}

This paper is a result of a project funded by the United Nations High Commissioner for Refugees (UNHCR), but which was independently carried out by researchers from the Maastricht Graduate School of Governance | UNU-MERIT.

Availability of data and materials

The datasets and related material (e.g. questionnaires, do-files) used for the study are available from the corresponding author on reasonable request.

\section{Competing interests}

The IZA Journal of Development and Migration is committed to the IZA Guiding Principles of Research Integrity. The authors declare that they have observed these principles. 


\section{Publisher's Note}

Springer Nature remains neutral with regard to jurisdictional claims in published maps and institutional affiliations.

\section{Author details}

${ }^{1}$ Maastricht Graduate School of Governance, Maastricht University | UNU-MERIT, Maastricht, the Netherlands. ${ }^{2}$ Utrecht University, Utrecht, the Netherlands.

Received: 3 August 2018 Accepted: 27 December 2018

Published online: 27 February 2019

\section{References}

Alix-Garcia J, Saah D (2009) the effect of refugee inflows on host communities: evidence from Tanzania. World Bank Economic Review 24(1):148-170.

Alix-Garcia J, Walker S, Bartlett A, Onder H, Sanghi A (2018) do refugee camps help or hurt hosts? The case of Kakuma, Kenya. Journal of Development Economics 130:66-83.

Alloush M, Taylor JE, Gupta A, Rojas Valdes Rl, Gonzalez-Estrada E (2017) Economic life in refugee camps. World Development 91:334-347.

Bakewell O (2000) Repatriation and self-settled refugees in Zambia: bringing solutions to the wrong problems. Journal of Refugee Studies 13(4):356-373

Betts A, Bloom L, Kaplan J, Omata N (2014) Refugee economies: rethinking popular assumptions. University of Oxford, Oxford, Humanitarian Innovation Project.

Callamard A (1994) Refugees and local hosts: a study of the trading interactions between Mozambican refugees and Malawian villagers in the district of Mwanza. Journal of Refugee Studies 7(1):39-62.

Chambers R (1986) Hidden losers? The impact of rural refugees and refugee programs on poorer hosts. International Migration Review 20(2):245-263.

Clemens M (2017) What the Mariel boatlift of Cuban refugees can teach us about the economics of immigration: an explainer and a revelation. Center for Global Development, Washington DC.

Crawford N, Cosgrave J, Haysom S, Walicki N (2015) Protracted displacement: uncertain paths to self-reliance in exile. Overseas Development Institute, London.

Easton-Calabria E, Lindsay A (2013) Towards durable solutions for protracted Congolese refugees in Rwanda. Oxford Monitor of Forced Migration 3(2):58-66.

Hovil L (2011) Shadows of return: the dilemmas of Congolese refugees in Rwanda. Citizenship and displacement in the Great Lakes Region Working Paper 6. International Refugee Rights Initiative (IRRI), New York.

IDMC (2016) Global report on internal displacement. Internal Displacement Monitoring Centre, Geneva.

Kreibaum M (2015) Their suffering, our burden? How Congolese refugees affect the Ugandan population. World Development 78:262-287.

Martin S (2016) Rethinking protection of those displaced by humanitarian crises. American Economic Review: Papers \& Proceedings 106(5):446-450.

Maystadt J-F, Duranton G (2014) the development push of refugees: evidence from Tanzania. Economics Working Paper Series 2014/019. The Department of Economics, Lancaster University Management School, Lancaster.

Maystadt J-F, Verwimp P (2014) Winners and losers among a refugee-hosting population. Economic Development and Cultural Change 63(4):769-809.

Milner J, Loescher G (2011) Responding to protracted refugee situations: lessons from a decade of discussion. Forced Migration Policy Briefing 6. Refugee Studies Centre, University of Oxford, Oxford.

Polzer T (2004) "We are All South Africans Now:" The Integration of Mozambican Refugees in Rural South Africa. Forced Migration Working Paper Series 8. Forced Migration Studies Programme, University of the Witwatersrand, Johannesburg.

Ruiz I, Vargas-Silva C (2013) The economics of forced migration. Journal of Development Studies 49(6):772-784.

Ruiz I, Vargas-Silva C (2016) The labor market consequences of hosting refugees. Journal of Economic Geography 16(3):667-694.

Taylor JE, Filipski MJ, Alloush M, Gupta A, Rojas Valdes RI, Gonzalez-Estrada E (2016) Economic impact of refugees. Proceedings of the National Academy of Sciences of the United States of America 113(27):7449-7453.

Tumen S (2016) The economic impact of Syrian refugees on host countries: quasi-experimental evidence from Turkey. American Economic Review: Papers \& Proceedings 106(5):456-460.

UN (2012) United Nations Rwanda Delivering as One Annual Report 2012. United Nations Rwanda, Kigali.

UNHCR (2016). Rwanda: Population of Concern to UNHCR. Retrieved November 12016 from http://www.refworld.org/ country,UNHCR,RWA,57d7ec294,0.html. United Nations High Commissioner for Refugees, Geneva.

UNHCR (2017) Global Trends: Forced Displacement in 2016. United Nations High Commissioner for Refugees, Geneva.

UNHCR (2018) Population Statistics. Retrieved 28 September 2018 from http://popstats.unhcr.org. United Nations High Commissioner for Refugees, Geneva.

Whitaker BE (1999) Changing opportunities: refugee and host communities in western Tanzania, Working Paper No. 11. New Issues in Refugee Research. United Nations High Commissioner for Refugees, Geneva.

World Bank (2011) Volume II: study on impacts and costs of forced displacement: state of the art literature review. World Bank, Washington DC

World Bank (2016a) Forcibly displaced: toward a development approach supporting refugees, the internally displaced, and their hosts. World Bank, Washington DC.

World Bank (2016b) Rwanda economic update: Rwanda at Work. Issue No. 9. World Bank, Washington DC.

World Bank (2017) Reshaping urbanization in Rwanda: economic and spatial trends and proposals, Note 2: Internal Migration in Rwanda. World Bank, Washington DC. 